\title{
IMIGRAÇÃO JAPONESA PARA O AMAZONAS NO PÓS-GUERRA SOB A PERSPECTIVA DOS HÁBITOS ALIMENTARES: (1953-1967) ${ }^{1}$ \\ JAPANESE IMMIGRATION FOR THE AMAZONAS IN \\ THE POST-WAR ON THE PERSPECTIVE OF FOOD \\ HABITS: (1953-1967)
}

\section{Linda Midori Tsuji Nishikido}

Resumo: Esta investigação visa reconstruir e reinterpretar a história da imigração japonesa para o Amazonas no pós-guerra, por meio dos hábitos alimentares, com enfoque para a Colônia Bela Vista e Colônia Efigênio de Salles, do período que compreende entre a retomada da imigração japonesa (1953) e a implantação da Zona Franca de Manaus (1967). Empregou-se como método a história oral, realizando as entrevistas como meio para coletar as informações. Como fundamentação teórica, adotou-se os preceitos de Jacks Le Goff que alça discussões sobre Memória e História, elementos norteadores da investigação. A importância da temática está atrelada ao fato de que alimentar-se para o ser humano não se resume apenas em saciar a fome, mas encontra-se carregada de simbologias que culminam na identificação de uma etnia. Nesse sentido, desenvolveu-se, por meio dos hábitos alimentares, aspectos relativos a sociedade e cultura dos imigrantes japoneses no Amazonas, estruturados nas práticas alimentares.

Palavras-chave: imigração japonesa; Amazonas; hábitos alimentares; imigrantes.

Abstract: This research aims to reconstruct and reinterpret the history of Japanese immigration to the Amazon in the post-war period, through eating habits, focusing on the Bela Vista Colony and Efigênio de Salles Colony, the period that included the resumption of Japanese immigration (1953) until the establishment of the Manaus Free Trade Zone (1967). Oral history was used as method, conducting interviews as a means to collect information. As a theoretical basis, the precepts of Jacks Le Goff were adopted, which

1 Artigo submetido em 30/03/2018 e aprovado em 24/11/2018.

2 Professora Substituta do Departamento de Línguas e Literatura Estrangeira, Faculdade de Letras (FLet), Universidade Federal do Amazonas (UFAM), Manaus; Mestre pelo Programa de Pós-Graduação em Língua, Literatura e Cultura Japonesa da Universidade de São Paulo; lindanishikido@ymail.com (ORCID iD https://orcid.org/0000-0001-9193-8712). 
raises discussions on Memory and History, guiding elements of the investigation. The importance of the theme is linked to the fact that food for the human being is not just about satisfying hunger, but is loaded with symbologies that culminate in the identification of an ethnicity. In this sense, aspects related to the society and culture of Japanese immigrants in the Amazon were developed through eating habits.

Keywords: immigration; Amazonas; eating habits.

\section{Introdução}

De modo geral, classifica-se a inserção da imigração japonesa para o Amazonas no pós-guerra conforme três categorias espaciais: Região do Baixo Amazonas, Colônia Bela Vista e Colônia Efigênio de Salles. O pioneiro grupo, de caráter dirigida, seguiu para a Região do Baixo Amazonas, em março de 1953, ficando conhecido como juto imin, literalmente imigração de juta, pois tinha como objetivo trabalhar na produção de juta, nas propriedades das fazendas dos imigrantes japoneses assentados antes da guerra. Em setembro de 1953, com administração regida pelo governo federal, iniciou-se o assentamento de imigrantes japoneses na região denominada Colônia Bela Vista, atualmente pertencente ao município de Iranduba. A partir de novembro de 1958, grupos de imigrantes adentraram no trecho da rodovia Manaus-Itacoatiara, sob a jurisdição estadual, com o intento de desenvolver a produção agrícola no estado.

Este estudo irá abordar temática relacionada aos hábitos alimentares dos imigrantes, das circunstâncias que compreende entre a retomada da imigração japonesa (1953) e a implantação da Zona Franca de Manaus (1967), baseada em relatos orais das pessoas que vivenciaram o fenômeno. A importância da periodização está atrelada ao fato de que os imigrantes ousaram de criatividade na cozinha, reinventando culinárias ditas japonesas empregando ingredientes do lugar imigrado, tendo em vista que não havia, na época, recursos próprios para o preparo de iguarias tradicionais japonesas, como a soja, base para o shôyu e miso ${ }^{3}$, em razão de fatores como a inadequação e aridez do solo. Além disso, mesmo havendo recursos semelhantes, o seu uso diferia, seja no paladar e no modo de preparo, se comparado a cultura alimentar do receptor. Tal diferença ocasionou estranhamento, a princípio, cuja reação não foi de passividade, isto é, procuraram reinventar e ressignificar culinárias japonesas com o que havia disponíveis, nomeando-as com termos híbridos, tais como shôyu de tucupi, miso de feijão de praia, tsukemono de mamão verde etc. Infere-se que a não passividade representa uma característica comportamental dos imigrantes japoneses possível de se identificar em outros setores da sociedade.

3 Pasta homogênea geralmente empregada no misoshiru, em temperos de legumes e verduras, e ainda como pasta de base para fazer tsukemono. 
Com a implantação da zona de livre comércio, em 1967, iniciou-se o processo de transformação significativa nos hábitos alimentares dos imigrantes, tendo em vista que o comércio de Manaus passou a dispor de produtos industrializados oriundos diretamente do Japão, assim afirma o colaborador Bruno Huang, empresário pioneiro na venda de produtos alimentícios importados do Japão, na década de 70: "Nori e biscoito né. E konbu. Aquela época saia muito konbu, daqui para São Paulo né." Entre os de gêneros alimentícios, produtos como shôyu, miso, nori, konbu, wakame,e biscoitos como okaki e senbei, poderiam ser facilmente adquiridos nas lojas importadoras da cidade, o que provocou uma diminuição na elaboração da culinária japonesa ressignificada, empregando ingredientes locais. Ademais, nesse mesmo período, os imigrantes japoneses encontraram alternativa de melhoria na produção de pimenta-do-reino, o que resultou na mudança de atividade econômica, da produção de farinha para produção de pimenta do reino. Esse procedimento resulta na diminuição da matéria-prima para a elaboração do shôyu à base de tucupi e a consequente interrupção do mesmo.

Assim, as riquezas alimentares reinventadas nos períodos iniciais encontram-se guardadas apenas na memória dos que realmente vivenciaram o período da imigração, tendo em vista que na atualidade, raramente se preparam tais culinárias.

Portanto, reconstruir a história da imigração japonesa no Amazonas por meio de hábitos alimentares, significa trazer à tona quesitos concernentes à vida cotidiana dos imigrantes, entrelaçando fatos e ações recheados de valores afetivos, além de permitir uma proximidade maior sobre o fenômeno da imigração.

Como método de investigação, adotou-se a história oral, cuja relevância, segundo Chiapetti (2010, p. 145):

[...] está na subjetividade do sujeito, que fornece às fontes orais elementos que nenhuma outra fonte seria capaz de dar, pode revelar sentimentos, significados, simbolismos e, até, a imaginação das pessoas. A riqueza de uma pesquisa com esta metodologia está na ênfase e na importância atribuídas aos sujeitos da pesquisa, construtores de seu destino, entre possibilidades e limites.

Assim, buscou-se principalmente os relatos orais das pessoas que realmente vivenciaram o fenômeno da imigração, sejam imigrantes, descendentes e não descendentes, devidamente autorizados pelos sujeitos entrevistados, conforme assinatura no Termo de Autorização elaborada pela pesquisadora. No caso da maioria dos imigrantes, a língua empregada foi o koroniago, visando a fluidez na entrevista.

A importância da temática está vinculada ao fato de que alimentar-se não constitui somente ato de saciar as necessidades biológicas. Para o ser humano, o alimentar é também um ato cultural, vez que é possível perceber aspectos que caracterizam a identidade de um grupo étnico. É como afirma Pacheco (2008, p. 219), baseado nos postulados de Mintz: 
Para os seres humanos, alimentar-se nunca é uma atividade puramente biológica, vez que, ela tem relação com o passado, com as diversas técnicas empregadas para encontrar, processar, preparar, servir os alimentos, atividades essas, que variam culturalmente e tem histórias próprias, condicionadas pelo significado que a coletividade lhes atribui.

Assim, quando as pessoas resolvem migrar para outras regiões, carregam na memória as lembranças gustativas que se apresentam fortemente marcadas, visto que envolvem as funções sensitivas. Significa afirmar que o ser humano adquire os seus hábitos alimentares junto a família, na infância, definindo as tendências alimentares, assim assevera Corner (2014, p. 263) "é na infância que o gosto é definido propiciando aceitação e recusa de pratos e de ingredientes, ou seja, os que fazem parte dos costumes e que a memória faz com que estejam presentes por estarem incorporados na cultura".

Desta forma, alguns questionamentos foram levantados: Como os imigrantes procederam ante a diferença nos hábitos alimentares? Quais hábitos alimentares foram adotados para se adaptar ao meio? Quais razões levaram os imigrantes japoneses a adotarem os hábitos alimentares ditas "japonesas" no Amazonas? Quais aspectos sociais e culturais encontram-se entrelaçados aos hábitos alimentares? São questionamentos que serão aclarados ao longo da pesquisa.

Como fundamentação teórica adotou-se os postulados teóricos de Jacks Le Goff (1990) que alça discussões a respeito de memória e história, elementos fundamentais que norteiam esta investigação. A inter-relação memória e história se deve, graças à evolução na concepção tanto da memória, quanto da história, isto é, hoje a ciência reconhece a importância atribuída a memória individual como fonte de investigação e a história, outrora restrita a narrativa cronológica, explora a história do tempo cíclico. Nesse sentido, para a história, os relatos orais buscados na memória, representam tanto como fontes primárias quanto objetos de investigação, pois o seu caráter subjetivo e dinâmico revestido de imperfeições, ao contrário de constituir em obstáculo, passa a ser tratado como recursos, permitindo fazer reflexões relevantes, inerentes aos aspectos sociais e culturais, com vistas a reconstituir valores e estabelecer identidades.

\section{Culinária dos imigrantes: criatividade e ressignificação.}

Na modernidade, a acessibilidade aos meios de comunicação e de transportes parece ter encurtado as fronteiras entre os países. No que cerne as culinárias, é possível hoje obter ingredientes e produtos da culinária japonesa nas prateleiras dos supermercados e lojas especializados em produtos japoneses ou pratos prontos para serem consumidos. As "culinárias japonesas" comercializadas como fast food são encontradas em diversos pontos da cidade, de modo que se podem consumir com frequência, pratos como sushi, 
sashimi, temaki, yakissoba etc. Entretanto, quando os primeiros imigrantes do pósguerra adentraram no Amazonas, não havia ingredientes para a elaboração de culinárias tradicionais japonesas, como a soja, assim como fator solo não se apresentava propício para desenvolver a cultura em questão. Recorreram-se, desta forma, aos recursos existentes no lugar imigrado, como o tucupi derivado da mandioca para fazer o shôyu, a macaxeira que resultava no bolinho semelhante ao mochi, as frutas tropicais como mamão verde serviu como tsukemono, a banana maturada para elaborar a pasta base de tsukemono, entre outros.

Nesse sentido, este capítulo busca apresentar as culinárias praticadas pelos imigrantes japoneses no Amazonas e analisar as razões que levaram a tais práticas, destacando os comportamentos dos imigrantes frente ao primeiro encontro com a alimentação do receptor e os primeiros anos da imigração no pós-guerra, tecendo considerações relevantes sobre aspectos históricos, sociais e culturais desses imigrantes no novo espaço.

\subsection{Trajetória Belém-Manaus: o primeiro encontro com as culinárias do receptor}

Para os imigrantes japoneses que adentraram no Amazonas, o primeiro encontro com a culinária local se deu durante a trajetória Belém-Manaus, dentro da embarcação brasileira, um convívio que durou cerca de uma semana a dez dias, tempo relativamente curto, porém suficiente para compreender a diferença cultural existente entre as duas etnias. A reação imediata foi de estranhamento, seguida de resistência, sobretudo para aquelas iguarias cujo paladar encontra-se cristalizado na tradição japonesa, por exemplo, o feijão doce em vez de salgado. A entrevistada Michiko Yano, no primeiro encontro com o feijão salgado, reagiu com reprovação, e não hesitou em acrescentar açúcar que sobrou do café da manhã. Por outro lado, a refeição como café da manhã foi aceita desde o primeiro momento, sendo adotada pela maioria dos imigrantes que substituiu a refeição matutina tradicional à base de gohan, misoshiru, tsukemono e okazu pelo café, leite e pão. Embora leve em consideração a subjetividade do sujeito, deduz-se que para as iguarias não habituadas no Japão, o nível de aceitabilidade foi maior, enquanto que para as culinárias em uso desde a infância, como o feijão adocicado, a aceitabilidade ao paladar local foi menor, como no caso do feijão salgado. São possibilidades recorrentes, pois "o homem se alimenta de acordo com a sua cultura e sociedade a que pertence, valorizando alguns ingredientes e desprezando outros" (CORNER, 2014, p. 262)

De qualquer modo, entre percalços e estranhamento, o encontro inicial com a cultura local representou para muitos, o princípio de uma aventura na selva amazônica, princípio este recheado de sabores exóticos que permeiam a trajetória desses imigrantes. 


\subsection{Hábitos alimentares no Barracão: o primeiro espaço}

O barracão foi o primeiro espaço onde temporariamente, os imigrantes fixaram residência por um período de aproximadamente dois meses até a construção de moradia nos terrenos concedidos pelo governo brasileiro. Durante esse período, as famílias compartilharam, na cozinha coletiva, conhecimentos culinários valorizando a convivência em grande família. Assim, a imigrante Michiko Yano relembra sobre o recheio de gyôza à moda chinesa, com carne de cutia: "Cheguei a comer carne de cutia ${ }^{5}$ que foi preparada como recheio de gyoza, por uma das senhoras imigrantes repatriadas de Manchúria, o que, portanto, conhecia o modo de fazer comida muito gostosa à maneira tipicamente chinesa" (tradução nossa). ${ }^{6}$ Percebe-se no fazer culinário, a riqueza cultural envolvendo um prato de origem chinesa, feitas pelas mãos da imigrante japonesa, com ingrediente da região amazônica, de modo que o pastel batizado como chinesa apresenta-se carregado de valores multiculturais. São características comparáveis ao povo judeu no que cerne à acumulação de riqueza cultural, pois sendo povo de caráter nômade, seus pratos são constituídos de mescla de ingredientes de diversos países (CORNER, 2014, p. 265).

Outrossim, encontram-se associados à prática alimentar os casos de doenças infantis assim comenta Sugako Nozawa, da primeira imigração na Colônia Efigênio de Salles. Ela afirma que o arroz trazido do Japão pela sua família ${ }^{7}$ e preparada na forma de $o k a y u^{8}$ ajudou sobremaneira na recuperação de crianças imigrantes abaixo de 10 anos que tiveram sintomas de febre alta, referindo-se a esses sintomas como sendo uma doença causada por ocupação de um espaço intacto, não habitado:

as crianças que vieram para o Brasil, os que vieram aqui, abaixo de 10 anos, todos adoeceram com febre alta. Deve ser porque vieram para um lugar ainda desabitado, no espaço novo. Eu tinha 11 anos e então não adoeci, mas as crianças com idade abaixo de mim, todos adoeceram com febre altíssima. Como se diz essa doença mesmo? Então, as crianças que vieram na segunda e terceira levas, não ficaram doentes. Então, como não tinha nada, preparou okayu e parece que o arroz trazido do Japão foi a salvação. (Sugako Nozawa, tradução nossa) ${ }^{9}$

\section{Espécie de pastel.}

5 Animal selvagem que vive na região, uma espécie de roedor.

6 合宿所で、クチアの肉をぎょうざのぐとして食べたことがある。あのおばさん満洲の引揚 者だったから、よく美味しい中国料理の作り方していたもの。

7 A imigrante refere-se a família Miyamoto, seu sobrenome de solteira.

8 Espécie de mingau de arroz, cozido somente com água.

9 お米はね、ブラジルに来た子供、ここに来た10歳以下の子供がみんな、高熱だしたのよ。 やっぱり新しい土地に入ると、ひとが住んでなかった所に入ると、なんか熱がきたのよ ね。私は11歳なってたから、ならなかったけど、その下の子供達、みんな高い熱だした の。なんか、何病って言うのかね。それでね、二次、三次の人はならなかった。それで、 
O relato da entrevistada perpassa a crença de que as crianças mais novas recebem influência do lugar desabitado, quando acontece o primeiro encontro com o novo espaço, manifestada com sintoma de febre alta, o que invoca no falar, os preceitos da cultura religiosa xintoísta, os quais todo ser é possuidor de espírito. Não obstante a pesquisadora tenha indagado sobre as causas da doença, a entrevistada não soube responder, pois não se realizou consulta médica ou exame laboratorial na época, mas deduz-se que o clima quente do Amazonas tenha contribuído para tal sintoma.

Pode-se afirmar que no geral, a convivência no barracão configurou-se como a vida em grande família, onde observa-se ajuda mútua, compartilhando circunstâncias de doenças e questões relacionadas à alimentação, um começo em que todos se encontravam no mesmo patamar, se observada pela ótica de concessão de terras.

\subsection{O passadio no lugar imigrado}

Para o imigrante, o distanciamento com a sua pátria suscita a percepção da identidade étnica e nesse processo, a alimentação é a primeira a ser evocada, pois se apresenta impregnada no organismo e na memória, sendo as comidas tradicionais, uma das principais formas de entrelaçamento com a terra pátria. É por isso que determinados ingredientes ou culinárias identificam a cultura de um país. No caso da cozinha espanhola, é marcada com azeite e alho, a cozinha italiana, o tomate e o orégano, a cozinha portuguesa, batata portuguesa e o louro, (CORNER, 2014, p. 270) e a cozinha japonesa pontua com o shôyu ${ }^{10}$ e miso ${ }^{11}$. Significa que as alianças familiares com o país de origem permanecem coesas ao longo dos anos através de inúmeros elementos culturais, como os hábitos alimentares, a língua, os costumes, assim revela os estudos de Yans-Mcloughlin (1990), numa abordagem fenomenológica e hermenêutica: o indivíduo, ao imigrar, não rompe os laços familiares, pelo contrário, fortalece o laço com a sua pátria. Da mesma forma, Táli Almeida (2014, p. 211) afirma:

As pesquisas etnográficas têm demonstrado que o imigrante está distante de ser o sujeito que rompe com as suas origens. Ao contrário, mantém viva e ativa a sua identidade com o país de origem por meio de uso corrente de língua materna e da culinária, da celebração de festas e datas comemorativas típicas do país de onde veio, juntamente com seus compatriotas.

子供たちが何もないから、おかゆ作るでしょう。で、その日本から持ってきたお米が助か ったみたい。

10 Molho à base de soja

11 Pasta à base de soja. 
Nesse sentido, o distanciamento com a pátria não significa esquecimento da cultura procedente. Pelo contrário, estar fora da fronteira territorial ativa ainda mais o desejo de pertencimento e de se identificar com a origem, de modo que as culinárias que remetem à pátria, apresentam um sabor especial, retrato simbólico de resistência e identidade. Entretanto, esse ideal identitário nada mais é do que o nascimento de uma nova forma de cozinha ${ }^{12}$, estabelecendo uma especificidade culinária, própria do lugar imigrado.

Assim, na ausência de ingredientes para a elaboração de culinária tradicional japonesa, considerando neste contexto o shôyu, miso e tsukemono, o imigrante passa a reproduzir iguarias que assemelham ao menos no visual, com os ingredientes da região receptora, por meio de experimentos e inovações.

O shôyu, normalmente preparado tendo como matéria-prima a soja, foi ressignificada com o líquido tucupi, extraído da mandioca. Segundo a colaboradora Tatsuko Tsuji: "Fazia shôyu com o tucupi extraído da mandioca, cozinhava, cozinhava e assim ficava com coloração escura como a de shôyu. Havia quem afirmasse que era mais gostoso do que o shôyu do Japão" (tradução nossa). ${ }^{13}$ Entretanto, durante a pesquisa bibliográfica a respeito do tucupi, descobriu-se que, na cozinha indígena, já se podia apreciar um molho semelhante, de sabor ímpar e de teor nutritivo, denominado tucupi pixuma, assim assevera Cascudo (2011, p. 588), consubstanciado nas afirmações de Alfredo da Matta (MCMXXXIX) e Stradelli (1929):

"[...]Tucupi pixuma, quando reduzido o volume à metade, sob a ação do calor e que torna o tucupi excelente e muito apreciado. Amazônia" (449) ${ }^{14}$. Stradelli era apaixonado pelo ticupi pixuna, "tucupi negro". É o sumo da mandioca fresca apurado ao fogo, até tomar a consistência e a cor do mel de cana. Para o meu gosto é o rei dos molhos, tanto para as caças, como para o peixe, devendo-se acrescentar que é aconselhado para a cura do beribéri, na dose de um cálice depois de cada refeição, e que se lhe atribuem curas extraordinárias (313) ${ }^{15}$.

Apesar da culinária indígena apontar a elaboração de molho semelhante ao produzido pelos imigrantes japoneses, observou-se que estes se referiam ao termo com certa naturalidade, mas nenhum dos entrevistados soube explicar quando emergiu a história do molho denominado shôyu de tucupi (tsukupi no shôyu). Assim, consciente ou não relativo ao preparo indígena, eles o empregavam em substituição ao molho de

12 Cozinha, neste contexto, está no sentido de arte de preparo das culinárias.

13 しょうゆはマンジオッカしぼったしるで、炊いて、炊いて、そうしたらしょうゆの色にな るの。むしろ、日本のしょうゆより美味しいって言う人もおった。

14 Número onde consta a referência de Alfredo da Matta.

15 Número onde consta a referência de Ermano Stradelli. 
soja, especialmente pela semelhança visual. Deduz-se que fatores como a quantidade deveras do líquido extraído da mandioca para a produção da farinha, a característica perecível do tucupi, a carência dos meios de transporte para a comercialização do líquido fez com que os imigrantes encontrassem um meio para evitar o desperdício, resultando no molho denominado de tsukupi no shôyu. Quando havia em excesso, utilizava o tucupi in natura nas casas de saúva, para o extermínio da mesma, pois o tucupi em estado natural contém um veneno letal, o ácido cianídrico, de maneira que procurava encontrar utilidade para o líquido. Há de se vislumbrar, por meio do uso de tucupi, a cultura do mottainai, termo outrora frequentemente empregado no Japão, sobretudo no período de escassez. Um dos significados está associado à questão cultural, em que se preservam valores como cuidado, zelo e sentimento de tudo que circunda o homem, seja bens materiais ou culturais. Por conseguinte, abarcam quesitos como disciplina, perseverança e responsabilidade, revelando a essência do pensamento do povo nipônico (NISHIKIDO, L., no prelo). Essa característica cumulativa apresenta-se notória na própria história japonesa, conforme assevera Yamashiro (1987, p. 20) consubstanciado nas afirmações de John Whitney Hall ${ }^{16: ~ "[. . .] ~ o ~ p r o c e s s o ~ e v o l u t i v o ~ d o ~ p o v o ~ n i p o ̂ n i c o ~ n a ̃ o ~}$ tem sido cíclico e sim linear e de crescimento cumulativo".

Outra culinária dependente de soja é miso, pasta que serve para fazer misoshiru ${ }^{17}$ ou como tempero para inúmeras iguarias. Na ausência de soja, empregou-se o feijão de praia, denominado pelos imigrantes como miso de feijão de praia. Infere-se que tal escolha do cereal deve-se ao fato de que o grão se assemelhava, ao menos aparentemente, à soja.

Outrossim, a escassez de verduras e legumes na região levou os imigrantes a recorrer para outros recursos que satisfizesse a necessidade do verde. Um deles foi o mamão, no seu estágio verde. Abundante nas terras amazônicas, a adaptação teve boa aceitação entre os nipônicos que rememoraram com saudosismo diversas culinária, tais como tsukemono, okazu e sunomono. O tsukemono de mamão era curtido à base de pasta de banana madura acrescida de sal ${ }^{18}$, cujo resultado tinha um sabor peculiar, salgado- adocicado, sendo o adocicado provido da banana. O okazu de mamão podia ser apreciado somente com óleo e sal, ou com outros temperos. O sunomono era preparado com mamão no estado verde-amadurecido, como afirma Tatsuko Tsuji: "Fazia sunomono $^{19}$ com mamão verde, um pouco amadurecido, descascava, cortava bem fino, deixava um pouco de molho no sal e depois lavava, colocava um pouco de vinagre e comia" (tradução nossa). ${ }^{20}$ Do mamão, até a raiz foi aproveitada em substituição ao

16 Historiador que estudou sobre o Japão desde os tempos antigos até moderno, registrado em sua obra Japan From Prehistory to Modern Times.

17 Espécie de caldo à base de miso.

18 Vide na descrição sobre banana.

19 espécie de salada, normalmente empregando pepino ao vinagre

20 すものは、マモンの青いのや、少しうれたのを皮向いて、細かく切って、塩もみして、少 しおいて、そして水で洗って、酢入れて食べた。 
kinpira gobo ${ }^{21}$, assim comenta Michiko Yano: "Fiz kinpira com a raiz de mamão. Lava a raiz, corta assim fininho, igual kinpira gobo. Coloca shôyu, tempera de modo salgadoadocicado, coloca pimenta e frita, fica igual bardana" (tradução nossa) ${ }^{22}$. É possível perceber que as experiências realizadas com mamão verde e a sua raiz são frutos do desejo de obter culinárias que remetessem à sua pátria e nesse processo reinventaram, na realidade, novos pratos tomados pelos sentimentos de saudade e vontade de consumir o que estavam habituados.

Outra forma de satisfazer a necessidade do verde, enquanto as plantações de sementes de hortaliças trazidas do Japão ainda não se encontravam no ponto de colheita, foi a coleta de broto de samambaia (warabi), dente de leão (burajiru tampopo), folha de vinagreira, palmito, cogumelos (kinoko) etc., embrenhando-se nas áreas desmatadas. No caso da Colônia Bela Vista, tinha ainda a opção de adquirir as verduras e frutas como tomate, maxixe, quiabo, laranja, jerimum, deslocando-se no final de semana até as várzeas próximas a região de Caldeirão ${ }^{23}$, a pé, a uma distância de 3 a 6 quilômetros, onde moradores da região comercializavam os produtos, assim comentam os imigrantes: Shigueko Kina: "Carregava (frutas e verduras)... japoneses iam em carência de frutas e verduras, aos sábados, iam a pé"; Hiromitsu Shishido: "Início não tinha verduras, as mulheres iam até várzea do Caldeirão para comprar verduras a pé" (tradução nossa) ${ }^{24}$. Nesse sentido, imaginar as pessoas, sobretudo as mulheres, carregando laranjas, jerimum, maxixe e quiabo, andando uma distância de quatro a seis quilômetros, há de se vislumbrar a dificuldade no regresso às casas e o esforço para saciar o desejo enraizado no organismo e na memória.

Dentre as opções de hortaliças recorrentes no Amazonas, o talo de inhame (zuiki) guarda na memória um sabor especial, assim comenta Hideko Sadahiro:

O que eu achei mais gostosa é o talo de inhame que fervido, descascado e secado tira-se todo o travo. Nisso, acrescenta-se o tempero como açúcar, sal, pinga, é realmente saborosa. No Japão, nunca havia consumido, e sabe, sinto muita saudade daquilo. Era realmente saborosa, secando até ficar crocante, tirando -se o travo, embora aparente um tom enegrecido. (tradução nossa) ${ }^{25}$

21 Culinária japonesa à base de bardana.

22 マモンの根っこでキンピラ作ったもん。根っこを洗って、こうして細く切って、ごぼうと いっしょ。しょうゆ入れて、甘辛くして、それにピメンタ入れてフリッタして、ごぼうと いっしょ。

23 Uma das regiões de assentamento pertencente à Colônia Bela Vista.

24 最初は、野菜が少ないから、ママイたちがバルジャまで野菜買いに行きよった。歩いて。

25 番美味しいと思ったのはサトイモのずいきをねインニャメを湯がいて、皮むいて、干した らあくが全部抜けてしまう。そしてそれをね、こんどあの、おさとう、しお、ピンガなど で炊いて、本当においしい。日本では食べたことが無かったけど。私、でも今あれが懐か 
Observa-se no excerto que, para a imigrante, não havia uma frequência em consumir talo de inhame em sua pátria, mas durante a investigação, observou-se que há referência ao produto na primeira obra literária do gênero diário, Tosa Nikki (Diário de Tosa), escrita em 935 por Kino Tsurayuki no período Heian conforme excerto da tradução a seguir:

Ano novo. Ainda continuamos no mesmo lugar.

O remédio seria apenas para aquela noite, de modo que foi colocado sobre a cobertura do barco. Aos poucos, foi se deslocando do local até cair no mar e não foi possível bebê-lo. Além de não haver talo de inhame e alga, típicos de ano novo, não haveria nada de consistente que pudesse servir para fortalecer os dentes e aumentar a longevidade. (NAGAE, 2014, informação pessoal, grifo nosso $)^{26}$

Nota-se que o talo estava associado ao consumo no período do Ano Novo e, portanto, um alimento especial. No lugar imigrado, a escassez de verduras fez buscar na memória um ingrediente que faz parte da culinária milenar, cuja recriação une as fronteiras entre as etnias. É como afirma Delgado (2006, p. 17): “[...] o tempo de memória ultrapassa o tempo de vida individual e encontra-se com o tempo da História, visto que se nutre, por exemplo, de lembrança de família, musicas, filmes, tradições, histórias escutadas e registradas". Significa afirmar que a memória se encontra em constante diálogo, não somente com o passado vivido, mas em conjunto com as reminiscências registradas nos lugares da memória.

$\mathrm{Na}$ época, a parca opção de hortaliças no Amazonas se explica pelo desconhecimento do povo interiorano no consumo desses alimentos, cujo prato principal consistia em peixe com farinha, conforme atesta Cascudo (2011, p. 493):

Toda população do interior do Brasil proscrevia de sua mesa as saladas, ervas, hortaliças, legume. No máximo, consentia os cheiros para a panela, os verdes decoradores da carne e do peixe. Feijão, milho, macaxeira, batatas. A farinha de mandioca, eram as concessões ao bom gosto dos velhos brasileiros.

Em outros termos, pode-se dizer que enquanto as verduras constituíam um dos pratos indispensáveis para os imigrantes japoneses, para os amazônidas, tinham apenas a função de tempero ou de decorador dos alimentos, simbolizando o

しい。ほんとうに美味しいんだから、カリンカリンに干すのよね。そしてあくが全部無く なってしまう。いろはちよっと黒くなるけどね。

26 NAGAE, Neide. Diário de Tosa. Arquivo pessoal recebida por e-mail neidenagae@gmail.com em 25 fev. 2016. 
quanto diferem na cultura alimentar. Além disso, nota-se, neste primeiro momento, a necessidade fisiológica da alimentação atuando como fator fundamental, talvez uma das primeiras necessidades sentidas pelo organismo.

Não menos importante, a constância de peixes de água doce auxiliou sobremodo o cotidiano alimentar dos imigrantes. Vale salientar que o consumo tradicional de peixes entre os moradores locais se resumia em assado, frito ou cozido, fresco ou salgado, acompanhado de farinha, assim como assevera Costa (1943, p.215): "Com pirarucu, tambaqui, tucunaré, pescada, e outros peixes, e ainda tartaruga e jacaré, preparam-se os pratos principais de alimentação do homem amazônico. Completam-nos a farinhadágua, o feijão e a macaxeira". Durante o processo de adaptação, os imigrantes japoneses aprenderam a consumir à moda da casa, mas não deixaram de buscar na memória, conhecimentos de sua pátria, elaborando em forma de peixe cru (sashimi), massa de peixe (kamaboko), sardinha ao vinagre (sunomono de sardinha), espécie de piracuí (tsukudani) etc.

O sashimi, se comparado com os peixes do mar, diferiam no trato pela quantidade excessiva de espinhas ${ }^{27}$, tendo que cortar as tiras numa espessura mais delgada. O sabor e a textura, bem como o visual também eram peculiares da região. A massa de peixe (kamaboko) era normalmente preparada com peixes de tamanhos maiores como o pirarucu e dourado, cujos espinhos eram fáceis de se retirar. Na época, empregava-se o moedor manual (minchi) para obter a massa. Nela, acrescentava-se ovos, trigo, sal e açúcar à gosto, adicionavam temperos verdes como cheiro-verde e cebolinha que depois de frito eram apreciados como tira gosto ou consumido no cotidiano. Nas festas como de casamento, podiam se desfrutar dessa iguaria, assim comenta Shizuko Kashimura (2015) que se casou em 1970: "Quem cozinhava eram todos issei. Não tinha nem miso, nem shôyu. No meu casamento fizeram kamaboko. A minha sogra comprou pirarucu fresco e fez kamaboko". (tradução nossa) ${ }^{28}$ Assim, até hoje esse hábito de fazer a massa com peixe da região é mantido entre os imigrantes e seus descendentes, considerado como mais saborosa do que a industrializada.

Em se tratando de Colônia Bela Vista, as proximidades dos rios e lagos, bem como a presença de pescadores ambulantes, permitiam obter peixes frescos, tais como jaraqui, pacu, sardinha, tucunaré, assim como atesta Nobuyoshi Tsuji: "Como comia peixes, pois vinham vender de Caldeirão" (tradução nossa) ${ }^{29}$. Cabe salientar que a presença de pescadores oferecendo peixes em domicílio, auxiliou sobremaneira os imigrantes japoneses da região que nos primeiros anos, não dispunham de meios de

27 De acordo com o livro Associação Koutaku do Amazonas, 2011, p. 60) "a grande quantidade de espinhas em "Y" e de diferentes tipos, dificultava o consumo. Houve quem enviasse espinhas em "Y" para os parentes no Japão dentro da carta, pois era uma coisa inusitada".

28 作る人はみんな一世だった。味噌もしょうゆもなかった。わたしの結婚式にかまぼこ作っ ていた。樫村のお母さんはピラルクフレスコを買って作った。 
transportes adequados, assim como atesta Nishikido, L et al. (2016, p.200) "O acesso ao pescado facilitava a vida dos imigrantes, pois na época não havia meio de transporte disponível". No caso da colônia Efigênio de Salles, havia um japonês veterano, de nome Mogui, que em seu jipe vendia peixes frescos e outros produtos, logo nos primeiros anos da colonização (Ken Nishikido, 2015). Assim, os peixes em estado viçoso permitiam consumir à moda de sua terra, o sashimi, seja de jaraqui, tambaqui, dourado, tucunaré, entre outros. Vale salientar que os japoneses têm certa resistência em consumir os peixes do rio in natura, por alegar existência de microrganismos nocivos à saúde humana. Contudo, transpondo esse saber ou essa crença, os imigrantes e seus descendentes no Amazonas consomem com naturalidade o sashimi de peixes dos rios..

Havia quem temperasse os peixes com sal e mirin ${ }^{30}$ ou pinga, conservando posteriormente com a pasta miso, conforme relata Hideko Sadahiro:

Como os peixes daqui são diferentes do mar, lavava-se com limão, temperava com mirin $^{31}$. Quando não tinha mirin substituía com pinga, acrescentava sal e conservava no miso. Deixando descansar por um dia, pode-se fritar assim mesmo, mas em geral, eu lavo, retirando o excesso. Coloca na frigideira, um pouco de óleo e frita, mas fica saboroso também, assado no carvão. É um sabor salgado (tradução nossa) $)^{32}$.

Observa-se no relato, a alternância do tempero mirim ou pinga, além do uso de miso para dar ao peixe da região, um sabor que lembra a culinária nipônica. Esse modo de preparo exprime o novo, pois a combinação dos ingredientes resulta numa iguaria peculiar da região amazônica. Deduz-se que no manejo peculiar da imigrante em preparar o peixe local com miso e pinga ou mirin, estão imbuídos sentimentos como saudades e recordações de sua terra pátria, porém nota-se também a identificação com o espaço imigrado no uso da pinga como forma de tempero.

Outro ingrediente, a princípio, de difícil aceitação pelos imigrantes japoneses foi a farinha. Apreciado na região como acompanhamento obrigatório de culinárias com peixes, a farinha foi adaptada e reinventada adequando ao paladar nipônico, transformando-se, nas mãos dos imigrantes, em novas iguarias. Assim, por exemplo, colocava-a sobre o arroz quente e deixava amolecer, formando uma consistência macia e viscosa, recorda Tatsuko Tsuji:

30 Espécie de sakê adocicado para culinária

31 Tempero com teor alcóolico usado na culinária japonesa.

32 貞弘秀子一あれはいったんきれいにしてね、ここのペイシは海のと違うから、リモンで洗 ってから、切ってそしてお味噌にねすこしみりんとか、みりんがなかったら、ピンガと か、そして塩もまぜたり、そして味噌につけて、一日おいたら、洗わなくてもそのまま焼 いてもいいけど、私一応洗うね。でフライパンに焼いて、あの油をしいて焼くとか。それ から、墨で焼いても美味しいけども。塩辛い味。 
Farinha foi difícil. Cozinhava o arroz, colocava em cima do arroz, lavava a farinha, então retira-se a parte que flutua, colocava em cima do arroz. Ficava viscoso, macio e assim, comia com arroz. Não dá para se comer puro por ser seco. Hoje não penso assim, até acho gostoso comer puro, bem diferente (Tatsuko Tsuji, tradução nossa $)^{33}$.

Nota-se que a imigrante se refere a farinha seca, cuja matéria-prima, a mandioca, não passa pelo processo de fermentação, resultando numa consistência seca, de difícil consumo, a princípio. Igualmente, misturou-se à farinha, açúcar e água, de modo que formava uma massa homogênea e quando aquecido numa frigideira untada de óleo, elaborava uma iguaria de consistência pegajosa, semelhante ao mochi ${ }^{34}$, nomeada de dango $^{35}$, apreciada no lugar do pão, conforme observa Shizuko Kashimura (2015):

Meu pai fazia dango e comia no lugar do pão. Misturava-se água e o açúcar, esperava tufar, colocava no fogo, ficava macio e até que era gostoso. Ele dizia " eu gosto é disso né". Colocava na frigideira um pouco de óleo, pra dizer a verdade um pouco parecido com o pé de moleque $e^{36}$ daqui. Fazia em formato de dango e como fazia no lugar do pão. Aliás, achava mais gostoso do que o pão. Colocando açúcar, tinha uma consistência de mochi (bolo de massa de arroz) (tradução nossa) ${ }^{37}$.

Observa-se, pelo relato, que o pai da entrevistada tinha preferência pelo bolinho de farinha, não por questão de economia, mas fazia lembrar a iguaria tradicional japonesa, "o mochi". Tal passadio remete aos primeiros imigrantes do Kasato Maru que preparavam o café da manhã com bolinho frito à base de farinha de mandioca ou milho. Porém, segundo Handa (1987, p. 62), o preparo tinha a intenção de conter as

33 ファリニャがジフィシウだった。ご飯炊いて、ご飯の上に、ファリニヤ洗って、そしたら 上に木が浮くでしょう。それを、ちょつとやわいのをご飯の上に乗せてベタベタになっ て、やわくなって、そしてご飯と食べた。そのまんま、パサパサして食べられないの。今 はそんなことないけど。今はそのまんまのほうがおいしい。ゼンゼン違うからね。

34 Há de se registrar a variação na elaboração do mochi que em regiões como São Paulo empregava arroz próprio, tipo mochi, o mochigome.

35 Bolinho de massa

36 Iguaria do norte à base de farinha de puba.

37 私の父はファリニャを団子にして、ぱんの代わりに焼いて食べてた。ファリニャに水と、 お砂糖も混ぜて、ふやかして、結構おいしかった。「俺はこれが好きでね」って言ってい た。フライパンに油をちょっとしいて、ここで言えば、ペデムレッケに似たような物が出 来てた。団子にしてね。よく作ってた。パンの代わりに食べてた。パンよりあっちの方が 好きだった。美味しいのは美味しかった。お砂糖入って、こねてると団子になっちゃう。 だから、もちもちするね。 
despesas: "Comia arroz três a quatro vezes ao dia, mas por motivo de economia, pois as refeições limitadas ao arroz pesavam demais no orçamento, passavam a usar farinha de milho ou mandioca, fazendo bolinho frito para come-los na hora do café da manhã".

A farinha foi empregada também em conjunto com a pasta de banana para fazer a conserva de verduras e legumes (tsukemono), conforme relata a entrevistada Shizuko Kashimura:

\begin{abstract}
A banana fermenta né. Então, as verduras soltam um liquido ne, e aí fica tudo ensopado, não é? Aí você coloca farinha e aí fica tudo durinho. Então, colocase o sal e deixa fermentar as verduras. Até hoje faço isso. Farinha d'agua, seca, qualquer coisa. Coloca-se novamente a farinha, sal e as verduras. Por isso, vai acumulando né, mas o sabor não muda. Se o sabor adocicado da banana estiver fraco, põe-se mais banana. Não estraga porque fica azedo e assim as bactérias fogem, não aguentam (tradução nossa) ${ }^{38}$.
\end{abstract}

Vale ressaltar que, em termos de produção agrícola, a farinha representou, no início da colonização, como uma das poucas alternativas que denotou resultado satisfatório, visto que o cultivo de mandioca pode ser desenvolvido mesmo em terras áridas e sem técnicas refinadas (AGUIAR, 1982, p. 21). Além disso, a farinha, produto final derivado da mandioca, constitui acompanhamento necessário em iguarias à base de peixes e, portanto, possuindo ampla aceitação no mercado. Contudo, os imigrantes não deram continuidade na produção, pois transferiu-se para a atividade de pimenta-do-reino, em alta na década de cinquenta.

De modo geral, as reminiscências dos períodos iniciais da imigração são tomadas pelo sentimento de saudosismo pelos colaboradores, pois passados mais de sessenta anos, as experiências deixaram marcas indeléveis na memória, marcas estas constituídas de sabores, saberes, recriação, ressignificação, concomitante com as circunstâncias de grandes desafios e dificuldades, pois a memória traz à tona fatores como o estranhamento do lugar, trabalho árduo e as diferenças culturais. Pode-se inferir que esse conjunto de sentimentos e ações configurou como uma experiência ímpar, permeado e moldado pelas práticas e pelos hábitos alimentares.

38 バナナは発酵するでしょう。そしたら、野菜から出る水分があるでしょう。それ がベチャベチャになるでしょう。そしたら、ファリニャを入れて、すいぶんを 吸い取ると、カチカチにまるでしょう。また、そこに塩を入れて、発酵するの。 私、今でもしていますよ。ファリニャダグア、セッカ、クアウケルコイザ。そし て、また塩を入れて、また次を入れる。だから、たまってくるよね。味は変わら ない。甘みがなくなったら、またバナナを入れる。腐らない。酸っぱくなると、 菌が逃げちやうの。ナウンアグェンタ。 


\section{Conclusão}

O imigrante, ao sair de sua pátria, carrega consigo, além dos bens materiais, os bens culturais que identificam a sua etnia. Hábitos alimentares fazem parte do rol de bens culturais, talvez um dos primeiros a se manifestar dentro do território imigrado. Entretanto, a inexistência de ingredientes apropriados leva o imigrante a encontrar outras alternativas para elaborar culinárias de sua terra natal. Assim, ao observar os hábitos alimentares dos períodos iniciais da imigração japonesa no Amazonas, no pós-guerra, nota-se a riqueza na elaboração de iguarias tradicionais japonesas, empregando os elementos da região amazônica. Resultou, nesse processo, a ressignificação de culinárias japonesas, tais como shôyu à base de tucupi, miso de feijão de praia, tsukemono de mamão verde, pasta para tsukemono empregando banana madura etc. São culinárias híbridas que atingiu seu auge no período entre a retomada da imigração, em 1953, e a implantação da Zona Franca de Manaus, em 1967, quando produtos importados do Japão passa a oferecer gêneros alimentícios apropriados e os hábitos alimentares recheados de criatividades perdem a força. Outro fator de redução na elaboração do shôyu de tucupi se encontra na mudança de atividade econômica, ou seja, da produção de farinha para produção de pimenta do reino. Esse procedimento resulta na redução da matéria-prima, tucupi, e a consequente diminuição do shôyu à base de tucupi. São criatividades que se encontram em fase de esquecimento, uma vez que são práticas culinárias guardadas basicamente na memória dos imigrantes, estes atualmente na terceira idade, o que requer emergência em registrar tais ocorrências.

Outrossim, estudar os hábitos alimentares consiste em observar os aspectos sociais e culturais do povo imigrado, pois alimentar-se para o ser humano é também um ato cultural, isto é, não somente satisfaz a fome, mas por meio dele revela outros valores integrados, tais como as práticas sociais, os eventos comemorativos etc., possibilitando vislumbrar a vida cotidiana dos imigrantes japoneses no Amazonas.

\section{Referências bibliográficas}

AGUIAR, Pinto de. Mandioca: pão do Brasil. Rio de Janeiro: Editora Civilização Brasileira S.A., 1982.

ALMEIDA, Táli Pires de. Migração Internacional feminina: trajetórias entre Bolívia, Paraguai, Peru e Brasil. In HIRANO, Sedi; CARNEIRO, Maria Luiza Tucci. Histórias migrantes: um mosaico de nacionalidades e múltiplas culturas. São Paulo: Humanitas: FAPESP, 2014, p.205-232.

BHABHA, Homi K. O local da cultura. Tradução de Myrian Ávila, Eliana Lourenço de Lima Reis e Gláucia Renate Gonçalves. Belo Horizonte: Editora UFMG, 1998.

CASCUDO, Luiz da Câmara. História da Alimentação no Brasil. 4a. ed. São Paulo: Global, 2011. 
CHIAPETTI, Rita Jaqueline Nogueira. Pesquisa de campo qualitativa: uma vivência em geografia humanista. In GeoTextos. Bahia: vol. 6, n. 2, dez. 2010, 139-162. Disponível em: $<$ http://www.portalseer.ufba.br/index.php/geotextos/article/viewFile/4834/3583>. Acesso em: 24 fev. 2016.

CORNER, Dolores Martin Rodriguez. A cozinha étnica espanhola nos restaurantes de São Paulo. In: HIRANO, Sedi; CARNEIRO, Maria Luiza Tucci. Histórias migrantes: um mosaico de nacionalidades e múltiplas culturas. São Paulo: Humanitas: FAPESP, 2014, p. 261-287.

COSTA, Angyone. Indiologia. Rio de Janeiro: Livraria Editora Zélio Valverde. 2a . edição, 1943.

HANDA, Tomoo. Memórias de um imigrante japonês no Brasil. Tradução de Antônio Nojiri. São Paulo: T.A.Queiroz,: Centro de Estudos Nipo-Brasileiros, 1980.

, Tomoo. O Imigrante Japonês: história de sua vida no Brasil. São Paulo. São Paulo: T. A. Queiroz, Editor Centro de Estudos Nipo-Brasileiros, 1987.

LE GOFF, Jacques. História e Memória. Tradução: Bernardo Leitão ...[et al]. $5^{\text {a }}$. Ed. Campinas, SP: Editora da Unicamp, 1990.

NAGAE, Neide. Diário de Tosa. Arquivo pessoal recebida por e-mail neidenagae@gmail.com em 25 fev. 2016.

NISHIKIDO, Linda Midori Tsuji. Mottainainismo: Aspecto Cultural do povo nipônico. 2015. Anais do Simpósio Internacional de Língua Japonesa como Língua Global/ III Encontro de Pós-Graduandos em Estudos Japoneses. São Paulo: USP, 2015, no prelo.

NISHIKIDO, Linda Midori Tsuji et al. Encontro dos povos no Encontro das Águas: Oriente e Ocidente no Amazonas. In CHAVES, Maria do Perpétuo Socorro Rodrigues; CARVALHO, Nerine Lúcia Alves de. (orgs.). Economia Criativa: a experiência do observatório estadual de Economia criativa do Amazonas. Manaus: EDUA, 2016, p. 191-207.

PACHECO, Sandra Simone Morais. O hábito alimentar enquanto um comportamento culturalmente produzido. In FREITAS, Maria do Carmo Soares; FONTE, Gardênia Abreu Vieira; OLIVEIRA, Nilce de. Escritas e narrativas sobre alimentação e cultura. EDUFBA, 2008, p. 218-223. Disponível em: http://books.scielo.org/id/9q/13. Acesso em: 08 jul. 2015.

YAMASHIRO, José. História dos samurais. 2a . edição, Aliança Cultural Brasil-Japão/Massao Ohno Editores, São Paulo: 1987.

YANS-MCLAUGHLIN, Virgínia. Metaphros of Self in History: Subjectivity, Oral Narrative, and Immigration Studies. In Immigration Reconsidered: History, Sociology, and Politics. New York: Oxford University Press, 1990. 